\title{
Dravyaguna Vidhyan -Jivaniya Mahakashaya: Review Article
}

\author{
${ }^{1}$ Nilofar Shabbirkha Tadvi , ,2Namdeo K Dorkhande , ,3unita Paradkar \\ ${ }^{1,2,3}$ Department of Dravyaguna Vidhyan, Bhausaheb Mulak Ayurved Medical College, Nandanwan , \\ Nagpur, Maharashtra,India.
}

\begin{abstract}
Jivaniya Mahakashaya signified drugs beneficial for life.Charaka enlist this ten such medicament which can be used as Jivaniya. All of these herbs have their natural habitats basically in Himalaya region hence these drugs occur only in small pockets. Jivaniya ganas being very essential in functioning of the body in terms of providing energy, sustaining life activities and rebuilding can be compared to nutrients and immunity booster. Although some work has been done on identification of medicinal herbs mentioned under Jivaniya Mahakashaya, but still there is a need to identify the true representatives of this Jivaniya gana. The present article deals with taxonomical and medicinal properties of these Jivaniya Mahakashaya.
\end{abstract}

Keywords - Jivaniya Mahakashaya; Ayurveda; Medicinal plant; Herbs.

\section{INTRODUCTION}

- Ayurveda is consciousness based science for health and healing and it's simply states that in order for us to feel good and healthy. Group based classification of Dravya is well describe specially in Samhita i.e Charaka Samhita and Sushruta Samhita,two separate chapters C.Su.4 and S.Su.38 respectively grouping .[1],[2]

- The herbs listed in the group Jivaniya Mahakashaya those herbs that have life promoting action . All of these plants have their natural habitats in Himalaya particularly the north-west Himalaya in $\mathbf{J}$ \& K, Uttarakhand \& Himachal Pradesh between elevations of 1500 and 4000m as. Their natural habitats are specific in ecological environment.

- Jivaniya Dravyas are based on their excellence in providing energy and strength.

$$
\text { Jivan }+ \text { iya }(\text { pratyaga })=\text { Jivaniya }(\text { Life })+(\text { for the benefit })
$$

- The Jivaniya Mahakashaya signified drugs beneficial for life.

- Jivaniya gana is important ingredient of various Ayurvedic formulations although some work has been done on identification of medical plant mentioned under Jivaniya gana but still their need to identify the true representatives of this Jivaniya Group.

- The present communication deal with the taxonomical and medicinal properties of this herbal medicinal plant each with common action.

\section{MATERIAL AND METHOD}

Each drugs mentioned under Jivaniya Mahakashhaya was reviewed from Bhavaprakash nighantus and Charaka Samhita. All information was critically analyzed discussed and concluded.[3] 


\section{OBSERVATION- Jivaniya Mahakashya-}

\section{JIVAKA}

Botanical name: Malaxis acuminate D. Don, syn. Microstylis wallichii Lindl, syn.Malaxis wallichii Deb.

Family-Orchidaceae

Botanical Description: A terrestrial herbs, up to $25 \mathrm{~cm}$ high. Leaves: 3-5, elliptic acuminate, sheathing at base, flower: deep pink, terminal dense to lax racemes. Bulbs of different orchids like.[4]

Upyuktaanga: Pseudo bulb

Chemical constituents: Alcohol ( ceryl alcohol), Glucose, Rhamnose and Diterpenes.

Therapeutically uses: Raktapitta, Daha,Ksaya, Raktavikara,Karsya,Svasa, Kasa, Sosa.

Dose: $5-10 \mathrm{gm}$

\section{RISHABHAKA}

Botanical name: Microstylis muscifera Ridley

Family: Orchideaceae

\section{Taxonomical identification}

- Kingdom Plantea

- Sub kingdom - Viridaeplantae

- Phylum - Tracheophyta

- Class - Magnoliopsida

- Subclass - Lilidae

- Order - Asparagales

- Genus - Microstylis

- Species - Microstylis muscifera

Botanical Description: Herb 30-50 cm. Leaves; ovate, lanceolate. Flowers: yellowish green.[5] Upyuktaanga: Psedo bulbs

Therapeutically uses: Seminal weakness, burning and emaciation.

\section{MEDA}

Botanical name: Polygonatum verticillatum $\mathrm{L}$

Family: Aliaceae

\section{Taxonomical classification}

- Kindom - Plantae

- Clade - Angiosperm

- Clade -Monocots

- Order -Asparagales

- Family -Asparagaceae 
- Subfamily-Nolinoideae

- Genus -Polygonatum

- Species - Polygonatum verticillatum

Botanical Description: Polyagonatum verticillatum is a plant species of genus polygonatum. It is widespread in the Himalaya region.[6] It's a perennial growing to 0.45-1.2 m. Leaves: four to eight in a whorl. Flowers: 2-3 in bunch, in axils of the leaves, Fruits are red when ripe and remain hanging after the leaves have fallen.

\section{Upyuktaanga:Rhizome}

Chemical constitutes: Steroidal Saponins (Diosgenin), Protein and Resins.

\section{Therapeutically uses:}

Balroga,Bhagandara,Gulma,Kamla,Karsya,Kasa,Naktatandhya,Netrasrava,Rajyaksma,Raktapitta,Sosa,Svasa ,Timira,Visarpa.[7]

Dose: 3-6 gm curna

\section{MAHAMEDA}

Botanical name: Polygonatum cirrhifolium (Wall) Rolye

Family: Aliaceae

\section{Taxonomical identification}

- Kindom - Plantea

- Division - Cycadophyta

- Class - Liliopsida

- Order - Asparagales

- Family - Asparagaceae

- Genus - Polygonatum

- Species - Polygonatum cirrhifolium

Botanical Describtion : The polygonatum cirrhifolium covered kahenera polygonatum relatives Asparagaceae. [8]

Chemical constituents: Glucose, Sucrose

Upyuktaanga: Rhizome,Root

Therapeutically uses: Jvara,Raktavikara,Ksaya,Daha,Raktapitta,Balroga,Kamala,Ksrisna.[9]

Dose :3-6gm.

\section{KAKOLI}

Botanical name: Roscoea purpurea Smith

Family: Zingiberaceae

\section{Taxonomical identification}


- Kingdom - Plantea

- Clade -Angiosperm

- Clade - Monocots

- Order_Zingiberales

- Family - Zingiberaceae

- Genus _ Roscoes

- Species Roscoea purpurea

Botanical Description: A perennial rhizome herbaceous plant occurring in the Himalayas particularly Nepal.[10] Sometimes grown as an ornamental plant in garden. It can grow to over $50 \mathrm{~cm}$ tall with wide leaves although the height varies. The leaf sheaths are pale green or may have a dark reddish purple tinge. Forming clumps of thick, fleshy leaves from where fat stem arises topped by 1-2 purple hooded flowers in summer.[11]

Upyuktaanga: Tuberous root

Therapeutically uses: Raktapitta, Sosa,Jawara, Swasa,Kasa, Ksaya,Daha.[12]

Dose: 3-6gm

\section{KSHEERAKAKOLI}

Botanical name: Lilium polyphyllum D.Don.

Family:Aliaceae

\section{Taxonomical identification}

- Kingdom - Plantea

- Division - Cycadophyta

- Class_Liliopsida

- Family - Liliaceae

- Genus - lilium

- Species - Lilium polyphyllum

Botanical Description: It is a perennial, herbaceous plant that reaches heights of growth between 60 and $120 \mathrm{~cm}$. occasionally up to $240 \mathrm{~cm}$. In Himalayas at altitudes from 1800 to $3700 \mathrm{~m}$ endemic. The leaves are narrow and lanceolate. They are distributed around the stem.[13] Flowers: greenish-white, in cymes. Follicle: woody, turgid.

Therapeutic use: Seminal weakness.[14]

\section{MUDGAPARNI}

Botanical name: Phaseolus trilobus Ait

Family: Fabaceae

\section{Taxonomical identification}

- Kingdom - Plantea

- Phylum -Tracheophyta

- Class - Magnoliopsida 
Dr Maganti Anuradha*, International Journal of Ayurvedic \& Herbal Medicine 8(3) May.-June. 2018 (3253-3255)

- Order - Fabales

- Family -Leguminosae

- Genus -Phaseolus

- Species - Phaseolus trilobus[15]

Botanical Description : Phaseolus trilobus is 30 to $60 \mathrm{~cm}$ long herbs spreading on the ground, Roots sprouts from each node on the stem. Leaf oblong, Flowers $0.5 \mathrm{~cm}$ long yellow.

Upyuktaanga: Whole plant

Chemical constituent: Sterols

Therapeutically uses: Daha,Jwara,Vatarakta,Pittadaha,Musikavisa,Ksaya,Krimi,Pradara,Kustha.[16]

Dose: 3-5gm.

\section{MASHAPARNI}

Botanical name: Teramnus labialis Spreng.

Family:Fabaceae

\section{Taxonomical identification}

- Kingdom - Plantea

- Division - Cycadophyta

- Class - Magnoliopsida

- Family -Fabaceae

- Genus -Teramnus

- Species -Teramnus labialis

Botanical Description: Teramnus labialis is creeper resembling that of masha, Leaf having three leaflets compound 5 to $10 \mathrm{~cm}$ long oval, Fruit 2 to $5 \mathrm{~cm}$ long, cured pods with fur contains 8 to 10 seeds.

Upyuktaanga: Seed

Chemical constituent: Seed of watersoluble Gallactomannan Bioassayguided fractionation of aqueous and Alcoholic extract of Teramnus labialis yielded fraxidin[17]

\section{JEEVANTI}

Botanical name: Leptadenia reticulate W\& A

Family: Asclepiadaceae

\section{Taxonomical identification}

- Kingdom - Plantea

- Sub kingdom - Tracheotionta

- Division - Magnoliophyta

- Class - Magnoliopsida

- Subclass - Asteridae

- Order - Gentinales

- Family -Apocynaceae 
- Genus

- Species
-Leptadenia

- Leptadenia reticulate

Botanical Description: A Twining climber shrub with branches numerous, younger ones, glabrous. Stem: yellowish, corky, deeply cracked bark. Leaves: coriaceous, ovate, acute, glabrous above finely pubescent; base cordite. Flower: greenish-white or yellow in lateral or sub-axillary. Fruit: follicles, sub woody $6-9 \mathrm{~cm}$ tapering seeds $6 \mathrm{~mm}[18]$.

Upyuktaanga: Root

Chemical constituents: Hentriacontanol, Alpha-Beta Amyrin, Stigma sterol, Beta- Sit sterol and Flavonoids-Diosmetin and Luteolin.[19]

Therapeutic uses : Atisara,Daha,Jawara,

Ksaya,Kasa,Sosa,Mukharoga,Naktandhya,Netraroga,Raktaoitta,Trsna,Urahksata, Vrana.

Dose: $3-6 \mathrm{~g}$

\section{MADHUKA}

Botanical name: Glycyrrhiza glabra Linn.

Family: Fabaceae

\section{Taxonomical identification}

- Kingdom - Plantea

- Subkingdom - Tracheobionta

- Sub division -Spermatophyta

- Division - Magnoliophyta

- Class -Magnoliopsida

- Subclass - Rosidae

- Order - Fabales

- Family -Fabaceae

- Genus - Glycyrrhiza

- Species -Glycyrrhiza glabra

Botanical Describtion : Glycyrrhiza glabra is a herbaceous perennial, growing to $1 \mathrm{~m}$ in height distributed in subtropical and warm temperate region with pinnate leaves about 7-5 m long, with 917 leaflets. Flowers are $0.8-1.2 \mathrm{~cm}$ long, purple to pale whitish blue produced in loose inflorescence. Fruit is an oblong pod, 2-3cm long containing several seeds. Roots are stoloniferous [20][21]

Upyuktaanga : Root

Chemical constituent: Glycyrrhizin, Glycyrrhizin acid, Glycyrrhetinic acid, Asparagines, Sugars, Resin and Starch.

Therapeutic uses: Kasa,Svarabheda,Ksaya,Varna,Vatarakta.[22]

Dose: $2-4 \mathrm{~g}$ Churna

\section{IMPORTANT OF JIVANIYA MAHAKASHAYA}

\section{According To Modern-}

- The herbs listed in the group Jivaniya gana are those herbs that have life promoting actions. The major aspect that sustains life is Prana; the essence of oxygen that revitalizes the body's energy and 
feeds the mind. The tissues of the body are sustained by oxygen the gross aspect of Prana, but at the level of cell it is Prana that nourishes the cellular function. When there is no Prana or a stagnation of Prana disease or death occurs. Hence to sustain life one must maintain the function of breath that takes in Prana, the circulation that transport Prana and the digestive tract that absorbs Prana as part of the digestive function. (23)a

- According To Doshas- The Doshas must also be balanced as the Doshas according to Charaka are the ultimate cause of death, as it is the doshas having been aggravated that gives rise to decay of the tissues. To promote the longevity of the tissues the properties to Kapha that are nourishing and strengthening are utilized to counter the catabolic effect of Vata. The effect of the herbs in the groups Jivaniya are anabolic in their nature, having the quality of Kapha, hence they are building, nourishes and strengthening. (23)b

- According To Dhatu -In order to strengthen the tissue of the body one must first sustain Rasa Dhatu, the first tissue in the body that nourishes all other tissue establishing tissue strength and proper tissue formation Rasa Dhatu has similar qualities to Kapha and as such agent that increase Kaphain the body nourish and strengthen Rasa Dhatu .By strengthen and promoting strong Rasa Dhatuthe other tissue that are nourished by Rasa Dhatu will also be strengthen.(23)c

The common feature of the herbs listed in Jivaniya Mahakashaya is their Kapha promoting action nutritive qualities and Shukra increasing effect upon body.

\section{Karma-}

- An incredible body energizer that improve body's endurance and immunity.

- Support and maintains healthy systemic adequacy for physical performance and fight fatigue.

- Promotes healthy circulation and oxygen rich blood flow to all system in the body and eliminating the toxins which leads to a more balanced hormonal system.

- Promotes routine cellular health and support defense against pathogens.

- Contain nature's richest source of vitamins, iron, calcium, magnesium, folic acid, potassium and aluminum in small traces along with antioxidants. Pratinidhi Dravya of Jiviniya Mahakashaya

It is difficult for a person to procure their genuine drugs from Himalayan habitat. Now a day there are listed under endangered plant. Therefore the tradition of suitable substitutes had started

Table 1. Pratinidhi Dravya of Jivaniya Mahakashaya

\begin{tabular}{|c|c|}
\hline Drugs & Bhavprakasha Nighantu \\
\hline Jivaka & Vidari ( Pueraria tuberose DC.) \\
\hline Rhishabhaka & Vidari (Pueraria tuberose DC.) \\
\hline Meda & Shatavari (Asparagus racemosus Willd.) \\
\hline Mahameda & Shatavari (Asparagus racemosus Willd.) \\
\hline Kakoli & Ashvagandha (Withania somnifera Dunal.) \\
\hline Ksheerakakoli & Ashvagandha (Withania somnifera Dunal.) \\
\hline
\end{tabular}


Dr Maganti Anuradha*, International Journal of Ayurvedic \& Herbal Medicine 8(3) May.-June. 2018 (3253-3255)

Table 2. Properties and Actions of the Dravya of Jivaniya Mahakashaya

\begin{tabular}{|c|l|l|l|l|l|l|}
\hline S.No. & Name & Rasa & Guna & Veerya & Vipaka & Doshkarma \\
\hline 1. & Jivaka & Madhura & Guru, Snigdha & Sheeta & Madhura & V-P $\downarrow$ \\
\hline 2. & Rishabhaka & Madhura & Guru, Snigdha & Sheeta & Madhura & V-P $\downarrow$ \\
\hline 3. & Meda & Madhura & Guru, Snigdha & Sheeta & Madhura & P-R-V $\downarrow$ \\
\hline 4. & Mahameda & Madhura & Guru, Snigdha & Sheeta & Madhura & P-R-V $\downarrow$ \\
\hline 5. & Kakoli & Madhura & Guru, Snigdha & Sheeta & Madhura & V-P $\downarrow$ \\
\hline 6. & Kshirakakoli & Madhura & Guru, Snigdha & Sheeta & Madhura & V-P $\downarrow$ \\
\hline 7. & Mudgaparni & Madhura & Guru, Snigdha & Sheeta & Madhura & Tridosha $\downarrow$ \\
\hline 8. & Mashaparni & Madhura & Guru, Snigdha & Sheeta & Madhura & V-P $\downarrow$ \\
\hline 9. & Jivanti & Madhura & $\begin{array}{l}\text { Laghu, } \\
\text { Snigdha }\end{array}$ & Sheeta & Madhura & V-P $\downarrow$ \\
\hline 10. & Madhuka & Madhura & Guru, Snigdha & Sheeta & Madhura & V-P $\downarrow$ \\
\hline
\end{tabular}

$\mathrm{V}=$ Vata, $\mathrm{P}=$ Pitta, $\mathrm{K}=$ Kapha, $\mathrm{R}=$ Rakta, $\downarrow=$ Decrease

\section{DISSCUSION-}

- In the emerging scenario the health policies in India and across the globe have been emphasizing on reproductive and child health care and also exploring the flasibility of introduction traditional systems of medicine such as Ayurveda, to achieve better health care.

- Ten vegetable drugs are mentioned in Jivaniya Mahakashaya. Among them eight drugs are enumerated as Astavarga in nighantus period. Natural habitat of most of the herbs (Major source of the drugs present in Jivaniya Mahakashaya) is in the Himalaya region, which compled with their short life span makes their avability difficult, therefore bringing into existence the tradition of Pratinidhi Dravyas.

- Drugs of Jivaniya Mahakashaya are predominantly of Madhura rasa,Madhura vipaka, Sheeta virya and Snigdha guna, Jivaniya karma of these drugs seems to due to Dravyaguna Prabhava. Further the jivaniya guna shows to the Oja.

- Jivaniya karma of some of the drugs is good Rasayana with rejuvenating and further, these drugs are useful in promoting body fat, healing fractures, seminial weakness and works as antioxidant in the body.

\section{CONCLUSION-}

- Now the world is moving towards the plants base medicine or phytochemical medicine that strengthening bodily systems (especially the immune system or Oja which can fight foreign bodies) and help to destroy against pathogen without toxic side effect.

- The drugs of Jivaniya Mahakashaya enhance Oja thereby increasing vitality and strength. Because of this benifical effect those drugs can be used to promote health i.e "Swasthasya swasthya rakshnama" which is the foremost aim of Ayurveda. 
- All the drugs of this Mahakashaya have not been evaluated scientifically till date only a few researchers were conducted on the drugs of this group. Therefore studies regarding phytochemicals and pharmacological properties are the need of time.

- The above discussion clearly indicates that Jivaniya Mahakashaya are one of the important ingredients of increase vitality of life according to Ayurveda which has become endangered .The special laws must be planned by the government to plan it is cultivation and collection in order to protect it from getting loss from our planet.

\section{REFERENCE}

1. Agnivesha ,Charaka, Samhita Elaborated by Charaka and Dridhabala with the Ayurveda Deepika Commentary by Chakrapanidatta, Edited by Vaidya Yadavjii Trikamji Acharya, Chawkambha Vidyabhawan, Varanasi Reprint 2000 pp 65-101.

2. Sushruta, Sushruta Samhita, with the Nibandhasangraha Commentary of Sri Dalhanacharya, Edited by Vaidya Yadavji Trikamji Acharya, Published by Chaukhambha Orientalia, Varanasi, 1992 pp 161-163.

3. Bhavaprakash, Bhavaprakash Nighantu by , Commentary by Prof. K.C.Chunekar, Published by Chaukambha Bharti Academy Varanasi, 2010 pp 61 Haritaki varga.

4. Ayurvedic Pharmacopoeia of India Published by Government of India Ministry andPart 1 Volume 5

5. Seminar of Indian Studies, Institute of South and Central Asia, Faculty of Arts, Charles University Development of this Data Base of India Plant names was made possible by the generous funding of the Grant Agency of Charles University, Prague, Czech Republic 1998-2009.

6. The Plant List : A Working List of All Plant Species.

7. Ayurvedic Pharmacopoeia of India Part 1 Volume 62008 pp 111-112.

8. Species 2000 and IT IS Catalogue of Life 2014 Annual Checklist Species 2000 ; Reading or Reterieved on 26 May 2019.

9. Ayurvedic Pharnamacopoeia of India Part 1 Volume 52006 pp102-103.

10. WCSP (2011) World Checklist of Selected Plant Families, The Board OF Trustess of the Royal Botanic Gardens, Kew, Retrived 2011-10-11, Search for 'Roscoea purpurea'.

11. Wilford, Richard Roscoeas for the Rock Garden, "Quarterly Bulletin of the Alpine Garden Society, 1999 pp 67(1); 93-101.

12. Ayurvedic Pharmacopoeia of India Part 1 Volume 32001 pp 79-80.

13. Wolf Bunhard Dickore, Marcus Nusser Flora of Nanga Parbat (NW Himalayas Pakistan) An Annotated Inventory of Vascular Plant with Remarks on Vegetation Dynamils 2000, in: Engler pp 14, 225.

14. R.A Furasale, S D Patil, J Ethnopharmacol : 2010 Jun 16; 129(3) pp 416-9.

15. Globalnames Score 2018-4-21 2:045:45.0

16. Ayurvedic Pharmacopoeia of India Part 1 Volume 42004 pp 64.

17. Chopra; R.N Nayar, S.L, and Chopra, I.C, In; Glossary of a Indian Medicinal Plants, First Edition , National Institute of Science Communication CSIR, New Delhi, 1956 pp 241.

18. Data Base of Medicinal and Aromatic Plants in Rajasthan ID 0106, Birla Institute of Scientific Research all Rights Reserved.

19. Ayurvedic Pharmacopoeia of India Part 1 Volume 62008 pp73-74.

20. Huxley, A,ed, New RHS Dictionary of Gardening ISBN(1992) pp 0-333 -47,494-5.

21. Brown, D,ed, The RHS Encyclopedias of Herbs and their Uses, ISBN(1995) pp 1-3053-0059-0.

22. Ayurvedic Pharmacopoeia of India Part 1 Volume 11990 pp 127.

23. a,b,c Vaidya Aterya Smith Author Brenden Skudder vitalizing Herbs Jivaniya www.aterya.com 